石油技術協会誌 第 82 巻 第 4 号 （平成 29 年 7 月） $230 \sim 240$ 頁 Journal of the Japanese Association for Petroleum Technology

Vol. 82, No. 4 (July, 2017) pp. 230 240

\begin{tabular}{l}
\hline 講 演 \\
Lecture \\
\hline
\end{tabular}

低油価・低炭素環境への耐性力強化と自己変革に挑むメジャーの現況*

\author{
小 谷 一 雄 ${ }^{* * \dagger}$
}

(Received July 6, 2017 ; accepted August 25, 2017)

\title{
In response to a Low Oil Price and Lower Carbon World: The current status of the Supermajors and their measures for transformation
}

Kazuo Kotani

昨年暮れに栗原会長より石油鉱業連盟に対し, 従来か ら『協賛』している秋季だけでなく春季講演会での特別講 演につき依頼を賜り，本日このような形で非技術テーマで のプレゼンをさせて頂くことになりました。石油鉱業連 盟（1961 年設立）に四半世紀以上先立つ 1933 年設立とい う長い歴史と伝統を誇り, 日本の E\&P 業界を支える技術 者や学生の皆さんが会員の権威ある業界団体である石油技 術協会の特別講演会にお招き頂いたことを大変光栄に思い ます。

3 本立ての特別講演の最後のセッションということで, すでにお疲れのこととは存じますが，専門的技術論文のプ レゼンではありませんから, リラックスしてお聞きいただ ければ幸甚です。

\section{1.はじめに}

本日のプレゼンは，「低油価・低炭素環境への耐性力強 化と自己変革に挑むメジャーの現況」というタイトルにさ せて頂きました。

なお, このプレゼン内容は, 主としてメジャー各社の開 示情報などに基づき分析・考察したあくまでも私の個人見 解であり，石油鉱業連盟としての見解ではないこと，あら かじめお断りしておきます。この点，くれぐれも誤解なき ようによろしくお願いいたします。

2014 年後半以降，私どもが直面している Downturn サイ クルというのは, 中国などの需要の伸びが鈍化している一 方で, 米国のシェールオイルを含む供給サイドの過剰在庫, 供給過多状態の顕在化という需給ファンダメンタルズの要 因に起因するものです。

\footnotetext{
平成 29 年 6 月 13 日 平成 29 年度石油技術協会春季特別講演会にて講 演 This special lecture was delivered at the JAPT annual meeting held in Tokyo, Japan, on June 13, 2017.

** 三井石油開発株式会社 Mitsui Oil Exploration Co., Ltd

† Corresponding author : E-Mail : kazuo.kotani@moeco.com
}

昨年，1Q にいったん価格は底を打ったと見られていま すが，需給リバランスがいつになるのか，長いトンネルの 出口がまだ視界に入ってこない状態が今もって続いている 現状だと思います。

当初 6 か月の予定で始まった, 今年 1 月からの OPEC, non-OPEC 諸国による協調減産は, 過去に例を見ない高い レベルで順守されてはいるものの, 過剰在庫の解消にはい まだ至らず， 5 月末の OPEC 総会では， 7 月以降もさらに 9 か月間協調減産を延長する決定が行われました。

産油国によるこうした動きが需給リバランスに一定の効 果をもたらしたとしても, シェールガスやタイトオイルと いつた非在来型石油資源や大水深などの在来型の資源開発 などが，不断の技術革新をもって，従来に比べて極めて低 コストでの開発が可能となった現代および未来において, 油価に関しては 2014 年以前のような高価格レベルの再来 はあり得ないのではないでしょうか。換言すれば，業界の 新次元への構造的変革, INDUSTRY RESETがますます進 行するのが今回の Downturn サイクルだと個人的には思え てなりません。

INDUSTRY RESET の中で, メジャー各社の経営実態が ぞうなっているのか, 彼らが勝ち組であり続けるためにい かなる手を打っているのか, 彼らが推し進める自己変革に 秘められた戦略やビジョンに関する理解を深めることによ り, 少しでも日本の業界人の役に立てば, と考える次第です。

\section{2. 石油鉱業連盟と石油技術協会の相互協力 関係の重要性について}

本題に入る前に, 石油技術協会とは車の両輪のような共 存共栄の関係にある石油鉱業連盟の概要, ならびに石油技 術協会と石油鉱業連盟が相互に協力し合うことの重要性に ついて簡単に説明させて頂きます。 
・図 1 石油鉱業連盟の概要 :

石油技術協会の目的は「石油・天然ガスの採取事業に関 わる技術の進歩と会員相互の親睦を図る」ことと理解して いますが，石油鉱業連盟は「石油鉱業の健全なる発達を図 る」ことを目的として，1961 年に設立されています。

両組織における大きな相違点は, 石油技術協会は個人会 員をべースとし, 企業は賛助会員のステータスなのに対し, 石油鉱業連盟は企業単位の会員制組織であることです。昨 今の会員企業の統廃合などにより, 現在の会員数は, 正会 員 18 社, 特別会員 1 社となっています。

また，両組織に共通する点としては，事務局が大手町に ある経団連会館の 17 階のスペースおよび一部スタッフを 共有しており，いわゆる，シェアード・サービス・センター 化が進んでいると言えます。

・図 2 石油鉱業連盟の事業内容および石油技術協会と の協力促進 :

石油鉱業連盟の事業内容は大きく 3 つあります。1 つ目 は『エネルギー安定供給確保に資する政策課題の検討と推 進』で, 自主開発比率目標（2030 年に $40 \%$ 以上）の実現 に絡むものです。2つ目は『政府などに対する政策要望, 税制要望などの提出』で, 2016 年 11 月の JOGMEC 法改 正は最近の成果と言えると思います。 3 つ目は『情報・調 査活動, 広報・交流活動の推進』で, この活動事例として は, 年次刊行物「わが国石油・天然ガス開発の現状と課題」 の発行や, 若手社員を対象とした「石油・天然ガス開発基 礎講座」の実施が挙げられます。なお，この開発講座はす でに 44 回実施しておりますが, 今年は 100 名以上出席す る盛況ぶりでした。

石油鉱業連盟と石油技術協会はそれぞれの設立趣旨に 沿つて多岐にわたる活動を行っておりますが, 冒頭に申し 上げた厳しい事業環境, 新次元への構造的変革が進行する 中で，車の両輪として共通のゴールを目指し，共存共栄の ための互恵関係の強化を図っていくことがますます重要か つ不可欠であると思料します。両者間の一層の協力関係・ コラボレーションの進化を目指そうではありませんか。

\section{3.メジャーの業績・財務状況}

それでは, いよいよ本題に入ります。

はじめに,「変化し続けるメジャー+IOCs vs OPEC+ NOCs の力関係」というサブタイトルを付けておりますが, おさらいとして「一次エネルギーの主役, 石油・ガス市場 の変遷」につき, 簡単にレビューしたいと思います。

・図 3 一次エネルギーの主役＝石油・ガス市場の変遷：

上段の左図および中図は, BP 2017 Energy Outlookに よる燃料別一次エネルギー需要量のグラフで, 1965 年〜 2015 年までの 50 年間の実績值推移と 2035 年までの予測 值を表しています。一次エネルギーの需要量はこの 50 年 で 40 億トン $\mathrm{OE}$ (石油換算) から 130 億トン $\mathrm{OE}$ に, 3 倍 以上に増加しました。燃料別構成では, それ以前の石炭に 代わり, 石油が一次エネルギーの主役の座を占めているも のの, 一時 $50 \%$ 近かったシェアは昨今 $30 \%$ 台で推移して
います。また, 環境面で相対的優位なガスが $20 \%$ 台となり， 堅実に伸びてきています。

2035 年に向けた今後 20 年間の予測では, 70 億人から 90 億人への人口増加が見达まれることもあり, 全体とし ての一次エネルギー需要量は 2 割程度増加し 160 億トン OE 近くになると予測されています。一次エネルギーの主 役の座はかろうじて石油が占めるものの, 石炭とガスが 2 位の座を交替し, 化石燃料系の石油・ガス・石炭が三つ巴 の戦いとなる中, $2 \%$ 程度に過ぎない再生可能エネルギー が $10 \%$ のレ゙ルに向かって今後飛躍的に伸びるだろうと BPは予測しています。

上段の右図「1861 年〜 2015 年の原油価格推移」をご参 照下さい。石油が一次エネルギーとして利用されはじめ た 19 世紀後半, John D. Rockefeller の Standard Oil による 市場寊占化の進行に伴い, 原油価格 (Money of the day) が約 10 ドル / バレルという時代がありました。その後 19 世紀末に米国で反トラスト法が施行され, 独占資本の活動 が規制されて以降，1970 年代に OPECが台頭するまでの 70 年余りは, 石油需要の大幅拡大を優先志向する石油入 ジャーによる市場支配の時代が続きました。この間，2つ の世界大戦や大恐慌もありましたが, 原油価格が 1 ドル / バレル程度で長期的に低位安定したことが世界経済と技術 力の急速な発展・向上に多大な貢献を果たしたことは確か だと思います。

1970 年代に OPEC が台頭し始めてから現在に至るまで の間に，石油は二面性を持つように変貌しました。1つは 国家安全保障・エネルギーセキュリティ上の重要度の高い 戦略物資であると同時に, 価格変動 Volatility の極めて高 い相場商品 Commodity であるという二面性です。後者の Commodity としての特性より 1970 年代以降の油価レンジ は 2 ドルから 150 ドル弱の間で大きく振幅しています。

下段の一連の円グラフは, メジャーに代表される IOCs (International Oil Companies) と OPEC に代表される NOCs (National Oil Companies) との力関係の時系列的な 変化を示す目的のものです。1970 年代時点では, 当時セ ブン・シスターズと呼ばれたメジャー，すなわち IOCs が 世界の石油市場の $85 \%$ を支配していました。一方, NOCs の市場占有率は $1 \%$ に過ぎませんでした（グリーン部分 14\%は旧ソ連市場)。それが, 2007 年時点では完全に逆転 して, NOCs コントロールが 78\%となり, IOCs の占有率 は 6\%,「Available under Negotiation with NOC」の10\%を 加えても $16 \%$ に過ぎない状況に変貌しました。

また, 2015 年時点の世界の石油埋蔵量に占める OPEC の割合は $81 \%$ で, メジャー・IOCs は今や数\%の市場およ び資源占有率の死守に奔走せざるを得め, 未曾有の事業環 境に直面しているのが現実です。そして, 新たな資源ナショ ナリズムや地政学リスクの動向などにより, 両者の力関 係は今後もさらに変化し続けるものと推察されます。

- 図 4 主要財務指標 $\Leftrightarrow$ 健全性脆弱化の推移事例 【Chevron】:

メジャーの弱体化・脆弱化の実態の 1 つの事例として, 
3 大メジャーの 1 社である Chevron の 2012 年〜 2016 年の 主要財務指標の推移をまとめたスライドです。

まず，真ん中のグラフを見てください。Cash In-Flow と の Cash Out-Flow のバランスを見ると，2013 年以降は毎年 100 億ドル以上の Cash 収支マイナスという状況になって いるということが分かります。

左側のグラフが示すとおり, 2012 年に 250 億ドル超あつ た純利益は, 2014 年後半からの Downturn サイクル突入以 降年々減少し, 2016 年は 5 億ドルの赤字計上という状況 です。左下の ROCE (Return on Capital Employed ; 投下資 本利益率）についても，年々急落してきています。

右側のグラフは借入金と Debt Ratio の推移ですが, 2012 年時点で 120 億ドル程度だった借入金は 2016 年末時点で は 461 億ドルに膨れ上がり，8\%だった Debt Ratio は 3 倍 の $24.1 \%$ に悪化して, 健全性の脆弱化が進行しているのが 現況です。

-図 5 産油国および上流開発企業の信用リスク評価推 移 :

業界全体の健全性脆弱化の実態を説明する目的で, 有力 格付け機関の 1 つである S\&P 社による産油国および E\&P 企業の信用リスク評価の推移を示すスライドを用意しまし た。

左側の表は, 産油国格付けの時系列的変化をプロットし たものです。一番左側から 2014 年 5 月時点, 2016 年 5 月 時点, 2017 年 4 月時点における, 各国の信用リスク評価 の推移を表しています。

$\mathrm{S} \& \mathrm{P}$ 社の「格付け符号」は, 最上位ランク $\lceil\mathrm{AAA}\rfloor \sim\lceil\mathrm{BBB}-\rfloor$ までは投資適格水準，「BB+」〜「CCC」までは「投機的水 準」とカテゴリー区分されており，彼ら格付け機関による 評価符号次第で，金融機関などからの融資条件（借入枠お よび金利など調達コスト）が大きく左右します。ちなみに， 2014 年時点で「AAー」であった日本は 2016 年に 1 ノッチ 落ちて「A+」に，同じく「AA-」であったサウジアラビ アは 3 ノッチ落ちて「A一」に格下げされています。また, 「投機的水準」の低評価が付されると, 資金調達の難易度 が上がり破綻せざるを得ない事態に陥ることもあります。 国家財政が石油収入に大きく依存していた産油国では今回 のDownturn 発生以降, Sovereign Wealth Funds の取崩し や投資顧問会社任せからの脱却（In-House 化）の動きが 起きていますが, 中にはすでに国家財政が破綻寸前まで追 い込まれている国も出現しており，ブラジル，ナイジェリ ア，イラク，ベネズエラの各国はすでに「投機的水準」に 格下げされています。

右側の表は, E\&P 企業の格付け変化です。業界の中で 唯一「AAA」だつた ExxonMobil が, 昨年遂に 1 ノッチ格 下げになりました。今回の Downturn サイクルに突入後, Shell, Chevron, TOTAL 辺りも, 全て $1 \sim 2$ ノッチ格下 げされた格好です。

2008 年のリーマンショック後, 株式や債券よりも高リ ターンが期待できる石油市場に世界中の余利マネーが堰を 切って流れ込んできました。時を同じくして，米国では
シェール革命の勃発により非在来型資源開発が活発化しま したが，機関投資家や金融機関はいまだ信用力の乏しい新 興のシェール企業に対しても巨額の資金提供を行ったた め, シェールガスやタイトオイルの開発・生産量拡大にま すます拍車が掛かりました。しかし，2014 年後半に供給 過多・過剰在庫による需給ファンダメンタルズの崩れが顕 在化し，市況が大幅下落するとともに，機関投資家や金融 機関が一転してマネー引き揚げに転換, 格付け機関もエネ ルギー企業や産油国の格付け評価を格下げする「負のスパ イラル」状態が続いています。

- 図 6 メジャー各社の格付け状況一弱体化の実態－：

このスライドの左表は，格付け機関によるメジャー各社 の現在の信用格付け状況, 総資産額, 有利子負債などの比 率（Leverage）をまとめたものです。

右表は S\&P 社が信用格付けに適用している油価・ガス 価前提の一覧表ですが, OPEC が本年 1 月からの協調減産 を決めた昨年 11 月以降の 2016 年 12 月 14 日付けで更新 されたものです。2017 年と 2018 年の適用油価は Brent • WTI ともに 50 ドル / バレル, 2019 年以降については, Brent・WTI ともに 55 ドル / バレルと極めて保守的な油価 を前提としています。また, Henry Hub ガス価格について は, 2017 年以降ずっと 3 ドル / MMBTU で不変との前提 です。

OPEC と non-OPEC による協調減産は順守されれば一定 の「Establish a Floor on Pricing」の効果は期待できるものの, 需給ファンダメンタルズの分析では, 過剰在庫の解消には 時間を要し, 需給リバランスの長期化が見込まれること, また, 米国のシェール事業については, 技術の進化に伴い コスト競争力が強化され, 短期のリードタイムで増産が可 能な事業環境が生れているため, 油価の上值を抑える Cap 機能と先物市況での Backwardation が起こり易いこと, な ぞを S\&P 社はかかる conservative な油価前提を継続する 根拠として挙げています。

・図 73 大メジャーの業績・財務状況 :

3 大メジャーの 2016 年 $1 \mathrm{Q} \sim 2017$ 年 $1 \mathrm{Q}$ の四半期毎の 業績・財務状況を取りまとめたのがこの一覧表です。

上段コラムは各社の税後損益 PAT, ならびにその部門 別内訳です。部門別内訳の区分は会社によって異なり, ExxonMobil の場合は, 上流・下流・化学品の 3 部門+コー ポレート general という分類になっています。 LNG 事業が 強い Shell の場合は, 上流・インテグレーテッドガス (LNG)・ 化学品を含む下流の 3 部門+コーポレートという構成で公 表しています。また, Chevronの場合は, 単純に上流と化 学品を含めた下流の 2 部門+コーポレートという構成が開 示情報です。

中段コラムは各社の四半期決算毎の Cash Flow に関する 情報です。そして，下段コラムは借入金（Total Debt）・負 債比率に関する情報です。この表から各社の借入金の状況 はかなり厳しい状態が続いていることが分かると思います。

・図 83 大メジャーの税後利益（直近 5 四半期）:

メジャーの収益構造の歴史を振り返ると, 従来おおむね 
恒常的に 70 〜 $80 \%$ 以上の収益を稼ぎ出してきた上流部門 （緑色）が，今回の Downturn サイクル入り以降，業績の 足を引つ張るという未曾有の状況の出現の中, 下流部門 · 化学品部門 (オレンジ色) が Vertical integrated operations の強みを発揮し, 収益貢献し, 会社全体としての業績を何 とか取りつくろう構図になっています。

2016 年の通期決算で言いますと, Shell と Chevronの上 流部門は赤字, 唯一 ExxonMobil の上流部門のみが黒字 (全 社ベース PAT の $2.5 \%$ に過ぎない 1 億 96 百万ドル）とい う惨憺たる状態で, 各社共, ダウンストリームと化学品部 門の好業績が屋台骨を支えるのに大きな貢献を果たすとい う極めて異例な決算でした。

OPEC ・ Non-OPEC による協調減産効果が現れた 2017 年 $1 \mathrm{Q}$ は, 各社共上流部門の収益力はプラスに転じたものの, 昨今の 50 ドル / バレル割れの市況や長期化している需給 リバランス次第では再び悪化することも想定されます。

・図 9 メジャー各社の Cash Flow 状況 :

2016 年は, TOTAL・BP を含め, メジャー各社の Cash Flow ポジションは引続きマイナスが継続したことから, 各社共 Cash Flow のニュートラル化を 2017 年の最優先課 題と捉えています。

2014 年後半からの Downturn サイクルによって, 通常 の営業活動による Cash In-Flow では全く Cash が不十分と なったため, 各社とも借入拡大や社債発行などによる資金 調達に動くと同時に，脆弱化したバランスシートのリバラ ンスを図るべく, いまだかつてない大規模な Non-core 資 産の売却に取組んでいます。BG 買収によりメジャーの中 でも最も巨額の Cash 需要を抱える Shell は 2016 ～ 18 年 の 3 年間で 300 億ドルという Non-Core 資産売却を対外的 に確約，また，Chevronも 2016 〜 17 年の 2 年間で 50 〜 100 憶ドルの Non-core 資産売却を経営方針に掲げています。

Cash Out-Flow では，CAPEX 投資費用の抑制，操業費・ コスト削減努力の徹底, 低油価でも収益性が見达める事業 への傾注（例えば，米国 Permian Basin やいわゆるブラウ ンフィールド案件の優先取り組み) といつた経営優先課題・ 施策に全力投球する一方で, 四半期決算ごとのコンスタン 卜な配当支払や自社株買いによる株主還元を抜け目なく実 施している状況が見られます。

・図 10 借入金および Debt Ratio 推移：

次に, 借入金の状況ですが, 今回の Downturn 前の時点 では 6 18\%の範囲に収まっていた Debt Ratio は急激に 膨張し, 最も借入が少ない ExxonMobil でも, 2016 年末時 点では 19.7\%（428 億ドル）に増大・悪化しています。

昨年第 1 四半期に BG 買収を実施した Shell に至っては, 2016 年末時点で 925 億ドルの Total Debtを抱えており, Debt Ratio は $28.0 \%$ となっています。一般的に Debt Ratio が $30 \%$ 以上の企業は, 投資家や格付け機関からは要ウオッ チ企業として注視されます。

・図 11 株主への現金配当の実績推移：

メジャー各社は ROCEなど財務指標の健全化を目的と した自社株買いを含め, バランスシートの健全性リバラン
ス化に迅速に取り組んでいます。また，金融機関や機関投 資家などの市場に対しては，従来以上に透明性の高い情報 開示と具体的な定量指標の確約を励行し, 説明責任をきち んと果たすことをとても重視しています。その上で, ステー クホールダーに対する還元となる配当については, 我々日 本人には過剰と思われるほど配慮し, 優先的に継続実施す ることを異口同音に唱えています。ちなみに, 各社の配当 リターンは $3.5 \%$ pa 以上です。

\section{4. 自己変革(1)：勝ち組であり続けるための 健全性・B/S リバランスに向けた取り 組み状況}

こうした厳しい事業環境にあって, メジャーが勝ち組で あり続けるためのバランスシートリバランスに向けた取り 組みとして具体的にどんなことをやっているのか, 四半期 毎の決算公表時や機関投資家・アナリスト向け説明会と いった場で各社が開示している説明資料によって見てみま しょう。

・図 12 B/S リバランスに向けた取り組み状況 【ExxonMobil】 :

ExxonMobil の人員・コスト効率化の事例からご紹介し ます。

人員については, 2011 年から 2016 年の 5 年間で $27 \%$ 削 減しています。また, Cash による投資 OPEX 支出につい ては, 同時期の 5 年間で $23 \%$ 削減し, コストカット額は 130 億ドルとなっています。

・図 $13 \sim 14$ B/S リバランスに向けた取り組み状況 【Chevron】:

続いて, Chevronです。

Chevron が 2016 年の決算説明会で説明した, 2016 年 〜 2017 年の 2 年間を対象とする「経営方針・優先課題」 に関する資料（図 13）では, Chevron が「Improving Free Cash Flow」を最優先課題と位置付けていること, そし て 2017 年中には配当後 Cash Flowを positive, ないしは neutral にするための諸施策（具体的には CAPEX 投資予算 の削減やコスト削減など）を「Priority」と「Focus」を置 く事項としていることを明示しています。

豪州の 2 つの LNG プロジェクト立上げやカザフスタン Tengiz 油田拡張プロジェクトなどのコミット済みの巨額 な投資支出を抱える中で, Non-core 資産売却による Cashinにも注力しており，（図 14）のとおり，2016 年と 2017 年の 2 年間で 50 億ドルから 100 億ドルの Non-core 資産売 却を実施することを対外公表しています。

2016 年末時点での資産売却達成額は 28 億ドル程度で, まだ道半ばです。なお, 同社が「売却対象クライテリア (基 準)」として挙げているのは, Chevronとして妥当と判断 し得る適正価格（=売却益）を期待できるかどうかです。

（図 14）右側の「Cash Margin Growth」では, 同社の石油・ ガス net生産量の 2016 年実績と 2017 年計画を対比すると, 2017 年のほうが Cash Margin の高い生産量の割合が増加 する（=Cash-In Flow/収益性が改善する）見通しなるこ 
とを一生懸命アピールしています。

・図 $15 \sim 21 \quad \mathrm{~B} / \mathrm{S}$ リバランスに向けた取り組み状況 【Shell】 :

そして, Shell ですが，昨年 BG を買収した同社は 2016 年から 2018 年の 3 年間を「RE-SHAPING SHELL」の期間 と位置付け, BGとの統合による Transformation, 自己変 革をこの期間内にやり遂げることを対外コミットしてい ます。その中で, 優先度の高いポートフォリオは何か,

Downturn サイクルを如何にマネージするか, 明確な目標 を掲げて BG のインテグレーションを進めています。（図 15)

2016 年〜 2018 年の 3 年間の Cash の使い道に関する優 先順位としては, (図 16) のとおり, 最優先するのは借入・ 負債の減額, 2 番目が株主還元・配当, 3 番目は資本投資 抑制と自社株買いなどによる健全性確保を挙げています。

また, （図 17）のとおり, BG 買収後, 6,500人の人員削 減と 25 か所のオフィス・拠点閉鎖を実施しています。

3 年間で 300 億ドルの Non-core 資産の売却については, （図 18）のとおり，2016 年中の Deal としては計 47 億ドル を実行, その中には昭和シェル石油株式の出光興産への売 却, 英領北海資産の Chrysaor ヘのパッケージ売却が含ま れています。2017 年 1Q 決算説明会では, （図 19）のとお り, その後 157 億ドルの Non-core 資産売却が進展しており, 300 億ドルに対して約 $2 / 3$ の実現めどが立ったとしてい ます。

CAPEX 資本投資については，（図 20）のとおり，2016 年は厳格な投資規律方針に則り 2014 年対比 200 億ドル減 額の 270 億ドルが実績值ですが, 引き続き厳しい油価環 境にある 2017 年は 250 億ドル以内, 2018 年も $250 \sim 300$ 億ドルの総枠規制を継続することにより, 「RE-SHAPING SHELL」の 3 年での必達を目指す構えです。

2014 年時点で Shell・BG 両社合計額 500 億ドル弱だつ た OPEX コストも，（図 21）のとおり，2016 年は 100 億ド ル減の 390 億ドルを実現, 2 年間で $20 \%$ 以上削減の目標を 掲げています。

以上, ExxonMobil, Chevron, Shell の順に, 各社の開 示資料に基づき勝ち組であり続けるための B/S リバラン スに向けた取り組み状況を見てきましたが, 各社共, Noncore 資産売却や CAPEX 投資抑制, コス卜削減, 低油価で も収益性が見込める事業への傾注など, 俊敏かつ大胆に具 体的施策を実行している状況がお分かり頂けたかと思い ます。

\section{5. 自己変革(2)：思考・意識変革への取り組 み状況}

メジャー各社は「Free Cash Flowニュートラル化」と いう目先の最優先課題に加え,「バランスシート $(\mathrm{B} / \mathrm{S})$ リバランス」による財務体質の筋肉質化, 「Volatility・不 確実性への耐性力の強化」に向けた自己変革を加速させ る一方で, 従業員の思考・意識変革 (Mindset \& Cultural Transformation）による業態变革にも精力的に取り組んで
います。その事例を紹介します。

- 図 22 Mindset/Cultural Transformation 取り組み事例 【Chevron】 :

Chevron は，「Investment Priorities」（投資クライテリア） を今まで以上に厳格かつ綿密に決め, その範疇に入らない 資本投資は絶対不可として支出削減・予算コントロールす ることを, メッセージとして出しています。具体的には, 2017 年の資本投資 $(C A P E X+$ 探鉱 $)$ 予算 $=\$ 198$ 億ドル, $2018 \sim 20$ 年のガイダンス $=\$ 170 \sim 220$ 億ドルを設定し ています。

- 図 $23 \sim 24$ Mindset/Cultural Transformation 取り 組 み事例【Shell】：

Shell は BG 統合による「RE-SHAPING SHELL」完了後, 2019 年〜 2021 年時点での Transformation 目標を対外公表 しています。（図 23）および（図 24）の右側の赤線囲い部 分が, Shell が描いている 2020 年初頭段階での同社あり姿 とその具体的経営指標です。主要な定量経営指標は以下の とおり :

(1) ROACE (Return on Average Capital Employed ; 平均 使用資本利益率）：～10\%

(2) Free Cash Flow: $200 \sim 250$ 億ドル / 年

(3) Brent 油価前提 : 〜 60 ドル / バレル

油価前提は, 2019 年〜 2021 年時点でも比較的 conservative な 60 ドルを使用していますが, 油価耐性の強化・自己改造 により, 今回の Downturn 以前よりも稼げる Shell にすると いうことを市場への強いメッセージとして訴える意図が坦間 見られます。

\section{6. 自己変革(3)：技術力進化への不断の取り 組み状況}

「自己変革(3」は「技術力進化への不断の取り組み」です。 技術イノベーション領域の現状に関するエネルギー業界と 他業界との相対比較や, 各社の取り組み事例につき説明し ます。

・図 25 エネルギー業界は Digital Maturity 未成熟な業 界!! :

この資料は, MITSloan（マサチューセッツ工科大学） が Standardization, Digitalization などの技術革新, Digital Maturityに関して 2015 年に公表した分析結果のサマリー ですが，要約するとエネルギー業界は Digital Maturityに 関し, 他業界に比べ未成熟で遅れている業界, というのが MITSloanの分析です。

図表の中の, オレンジ色の楕円マークは「18 業種セク ターの中での Bottom 5 セクター」を表しており, 8 項目 中 3 項目で Bottom 5 に入っている “Oil \& Gas” セクター は, 18 業種中 14 位のランクという結果です。逆に言えば, Standardization や Digitalization, AI や IoT ・ Big Data 活用 などの技術イノベーションを図る余地がまだまだ大いにあ る業界との解釈が成り立ちます。

- 図 26 IT 技術による相対的優位性の維持・拡大： 実際にDigital Maturityに関しては, 例えば自動車, 航 
空産業, 発電・原子力業界などに比して未成熟で遅れてい るエネルギー業界だったわけですが，今回の Downturn サ イクルを機に, Standardization や Digital Transformation に よる技術イノベーションの積極活用と, E\&Pに固有な機材・ 作業などへのこれら革新的技術の適用といった動きが加速 化しつつあるようです。

特にメジャー各社はこれらの革新的技術を積極的に取り 込むこと，「技術力進化への不断の取り組み」をもつて， 業界内での相対的優位性の維持・拡大, 重複作業の解消・ 操業効率化や生産コスト引き下げによる Volatility・不確実 性への耐性力強化, 新たな収益基盤作りへの自己変革を志 向しています。

（図 26）下段部分は「デジタル・オイルフィールド」の 事例ですが，最新のデジタル技術を駆使することにより， データ計測・解析などの処理がワイヤレス通信, 自律稼働, ビッグデータ・AI 解析によって効率化され, 将来的には口 ボティクスによる作業代替などにさらなる進化を遂げるこ とが期待されます。

また, E\&P 業界は地質データにしろ, 開発・生産方法 にしろ，秘匿性を重んじる閉鎖的な業界でしたが，産油国 NOCs や探鉱・開発技術サービス関連企業などとの協働や 連携を強化する動きもメジャー各社は加速させています。

- 図 $27 \sim 28$ 技術力進化への不断の取り組み事例 【ExxonMobil】 :

ExxonMobil が本年 3 月 1 日に行つた『2017 Analyst Meeting』で説明した，「技術力進化による収益性向上」に 関するプレゼン資料をご紹介します。

（図 27）は技術革新による収益性改善に関するもので, $\lceil\mathrm{cMIST}$ in-line gas separation」による<25\%のコストの削 減と,「High manganese steels」という腐食性耐性に優れ た鋼管パイプ開発事例を紹介しています。

（図 28）は同社の低炭素社会・環境対応に関するもので, 2000 年以降の温暖化ガス削減関連投資額が 70 億ドル近い こと, CCS（Carbon Capture \& Storage）分野での第一人者 であることなどをアピールしています。

\section{7. まとめ}

最後に「まとめ」です。

2014 年後半からの Downturn 入りから 3 年が経過しよ うとしていますが，冒頭でもお話したとおり，いまだト ンネルの出口が見えない状態が続いております。今回の プレゼン資料は 5 月初めに事前提出しましたが, その時点 の市況に鑑みて「当面原油価格は 50 〜 55 ドルの Box 圏 市況が継続するとの見方が主流」と記載した次第です。 OPEC・Non-OPEC による協調減産の順守・実効性, 米国 シェールの増産状況，そして過剰在庫解消の長期化予測な どにより, 現時点では Box 圈が 5 ドル程度下振れしており,
正に “Lower for Longer” が当てはまる現況かと思います。

・図 29 まとめ1) :

かつては世界の石油市場をほぼ独占的に支配していたメ ジャーも, 資源ナショナリズムの進行や環境対応ニーズの 中で，今や数\%の市場・資源占有率の死守に奔走せざるを 得ぬ未曾有の事業環境に直面し, 強い危機意識を鋭敏かつ 適確に認識した上で, 先程説明した「3つの自己変革」, すなわち(1)勝ち組であり続けるための健全性・B/S リバラ ンスへの全力投球, (2)従業員の思考・意識変革による企業 体質の変革への果敢なチャレンジ，(3)メジャーのメジャー たるゆえんである技術力進化への不断のチャレンジ，にス ピーディかつ真摰に取り組んでいるように思います。

・図 30 まとめ(2):

米国のトランプ大統領が 6 月 1 日に「パリ協定」からの 離脱を表明しましたが, 世界人口の増加に伴う一次エネル ギーの需要拡大が長期的に見込まれる中で, 温室効果ガス 排出量の削減, 低炭素社会実現を目指すというグローバル なトレンドは歯止めが掛かることなく, 着実に前進するも のと思われます。

「パリ協定」が主要目的としている, 2050 年までの地球 温暖化プラス 2 度以内という目標をクリアするケースにお いても, 現在は $80 \%$ 以上を占めている石炭・石油・ガス =化石燃料への依存率は引続き $60 \%$ 程度を維持する, 依 存せざるを得ないという見方が一般的です。

したがって, メジャー各社は, 今後も「Oil \& Gas First」を大黒柱とする経営方針の立ち位置は不変であるも のの, 引き続き勝ち組であり続けるために, 大胆な自己変 革の実現による持続的成長を目指しているというのが現実 です。

そして「Oil \& Gas First」の旗は降ろさぬ一方で, 技術 力進化への不断のチャレンジを通じ, 低炭素社会への耐性 を高める多様化の追求, ならびにそれによる社会貢献や企 業価值・アカウンタビリティ向上も狙いとして, 従来以上 に積極的に取り組む方向性を打ち出しているように見受け られます。

日本には, 世界に誇れる最新の技術力を有する企業や研 究機関が多数存在しているわけですが, 我々石油開発業界 としても，これらの技術優位性を備えた他の日本企業とも もつと協力し合うべきではないでしょうか。そして，昨今 のメジャーの動向をしつかり把握・認識した上で, メジャー とのパートナシップのさらなる強化や, サービス会社など とのアライアンス強化に取り組むことが極めて重要でない かと考えます。斬新なパートナー戦略・地域戦略, NOC 戦略の構築といつたチャレンジを, 既成概念に囚われるこ となく適宜実行していく勇気が今必要とされているのでは ないか, というのが私のまとめです。

ご清聴ありがとうございました。 


$$
\text { 図一覧 }
$$

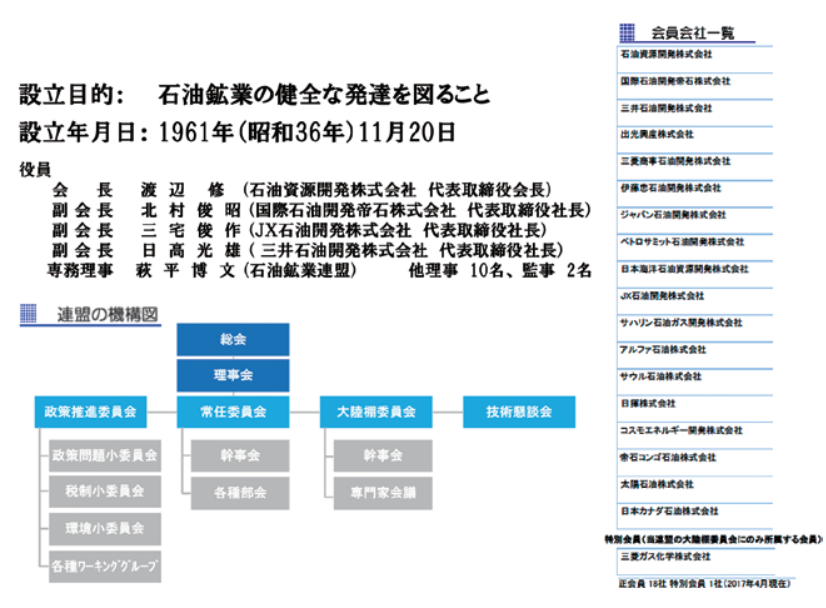

図 1 石油鉱業連盟の概要
口石油鉱業連盟(石鉱連)の事業内容

(1) 政策課題の検討と推進 くエネルギー安定供給確保〉

$\Rightarrow$ 自主開発比率目標 (2030年に $40 \%$ 以上)の実現

(2) 政府等に対し政策要望、税制改正要望等の提出

$\Rightarrow 2016$ 年11月JOGMEC法改正

（3）情報·調查活動、広報・交流活動の推進

一百油技術協会(技協)との協力関係・コラボレーションの進化 ・自主開発比率目標達成の為には、かが国石油開発技術の向上が不可欠 ・事務局運営における効率的共存関係や、石鉱連「資源評価ス夕ティ」 発刊等での協力関係は既に確立

・今後、双方が更なるコラポレーションの進化を図ることが共存共栄に

資するとの認識を共有

第7回资源詳価スタデの内容检討、執筆者選定の段階からの協力

秋季講演会に加え春季娾演会にわいても石鉱連が協賛

本春季講演会における講演の引を受け

> 今後の協力関係の促進を目指し、協議を継続

図 2 石油鉱業連盟の事業内容および石油技術協会との協力促進

The gradual transition in the fuel mix continues...

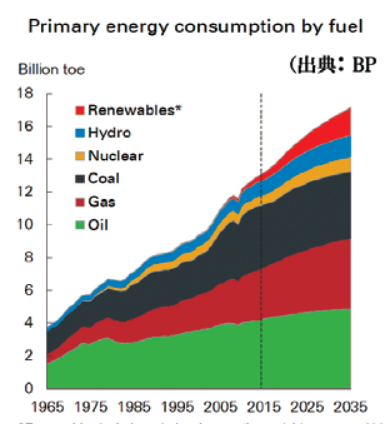

Shares of primary energy
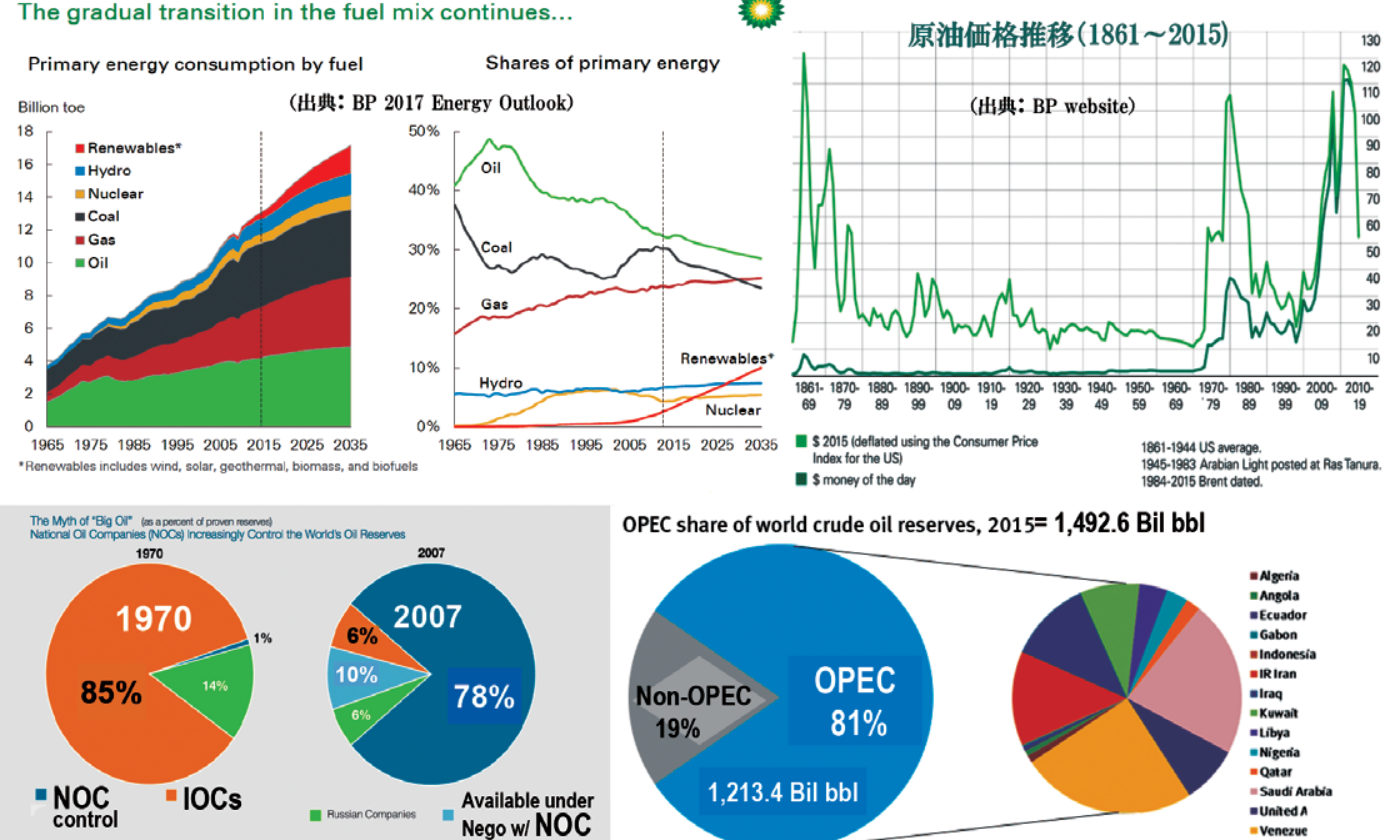

OPEC share of world crude oil reserves, $2015=1,492.6 \mathrm{Bil} \mathrm{bbl}$

出典：PFC Energy（一部䇤者加工）

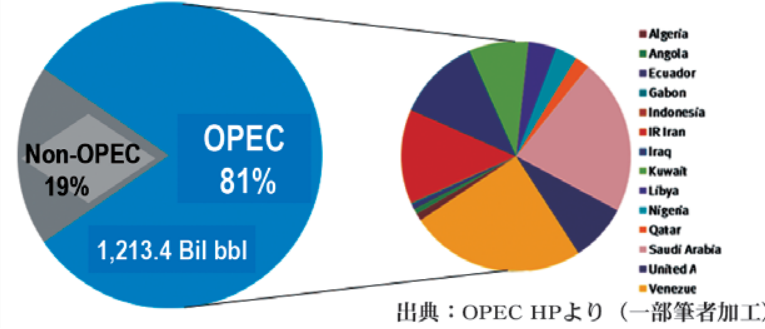

図 3 一次エネルギーの主役 $=$ 石油・ガス市場の変遷 -

変化し続ける〔メジャー+ IOCs $〕$ vs〔OPEC + NOCs $〕$ の関係一

【主要産油国の格付け変化】

\begin{tabular}{|c|c|c|c|c|c|c|c|}
\hline \multicolumn{4}{|c|}{ 【主要産油国の格付け変化】 } & \multicolumn{4}{|c|}{ 【主要上斎䦎發企業の格付け変化】 } \\
\hline 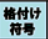 & 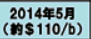 & $\begin{array}{l}\text { 2016年5月 } \\
\text { (1954/b) }\end{array}$ & 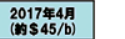 & 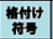 & 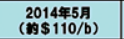 & $\begin{array}{l}\text { 2016年5月 } \\
\text { (19\$5 } 45 / \mathrm{b})\end{array}$ & $\begin{array}{l}\text { 2017年4月 } \\
\text { (岱 } \$ 45 / \mathrm{b})\end{array}$ \\
\hline AAA & tos & moty & mats & AMA & エצי & & \\
\hline $\mathrm{AA}^{+}$ & דועי & דוגוני & דועי & aAt & & エஅンイ(1) & בועי \\
\hline AA & UAE & $g x-k(t)$ & mat- & AA & :エル、シェ7ロン & & \\
\hline & & & & AA- & 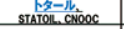 & $\sum x>a 2(1)$ & 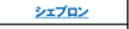 \\
\hline AA- & 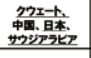 & 中国 & 中田 & At & 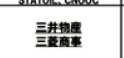 & 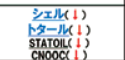 & 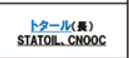 \\
\hline At & & 且本( $(1)$ & 且本 & A & 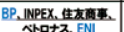 & 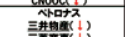 & $2 z \Omega(1)$ \\
\hline A & & & & & & $=3$ & \\
\hline A- & & 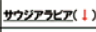 & 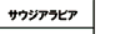 & A- & 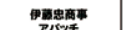 & 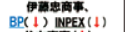 & 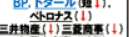 \\
\hline $888+$ & ב*⿻ & ב ב & ב ב & & & & \\
\hline B8B & & & 投资遠林 & BBB+ & 粪双 & EN(1) & $\mathrm{ENI}$ \\
\hline & & & & 888 & 太Ar. 多Jスマ\%, Hess & 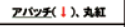 & 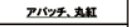 \\
\hline $680=$ & 罗然 & & I2P(t) & B88- & 사묵조 & 푹즈 (1), Hess $(1)$ & 고사. 스. Hess \\
\hline 88+ & & a: $2(1)$ & & BB+ $\div$ & & & \\
\hline 88 & & $72 \%(1)$ & $73 \%$ (统) & & & $x+a 72 x(1)$ & $x+972 \pi$ \\
\hline B8- & $\pm(1)=12 y$ & 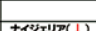 & 投拱的水年 & $\operatorname{ccc}$ & & & \\
\hline$\frac{B+}{B}$ & & $712 x+270$ & 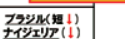 & & & WV $\Delta z$ & $\operatorname{Down}(t \downarrow)$ \\
\hline 8- & 197.스족 & 197 & 190 & & & & \\
\hline
\end{tabular}

図 5 産油国および上流開発企業の信用リスク評価推移

（格付け機関 S\&P 社による評価）

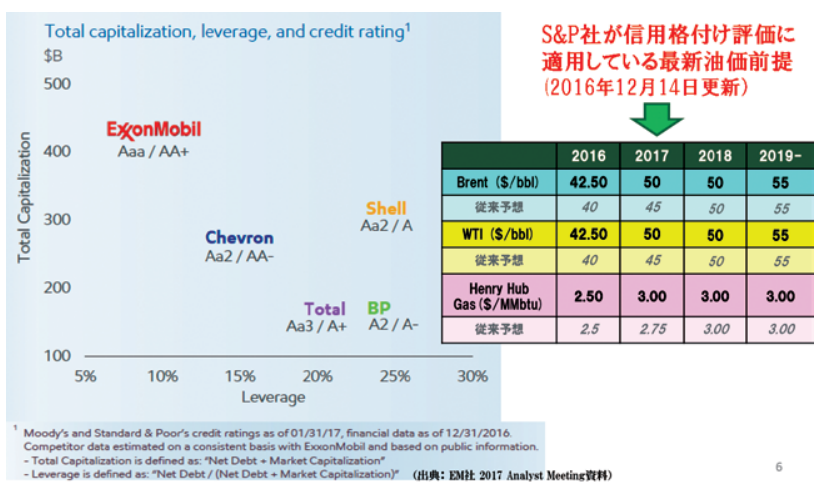

図 6 メジャー各社の格付け状況-弱体化の実態- 

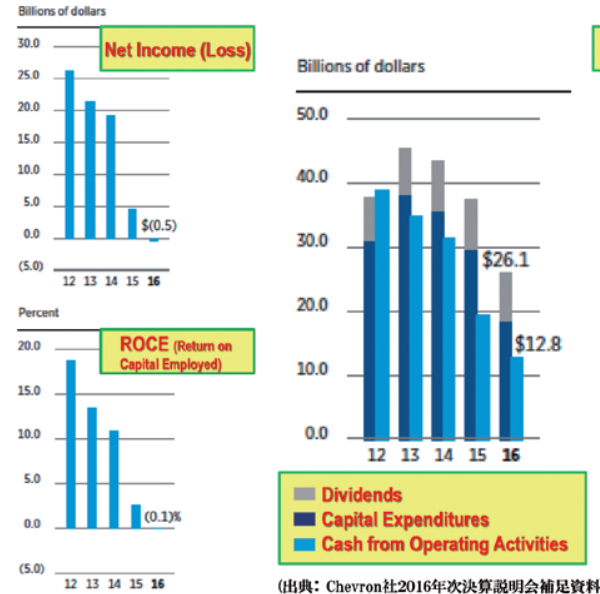
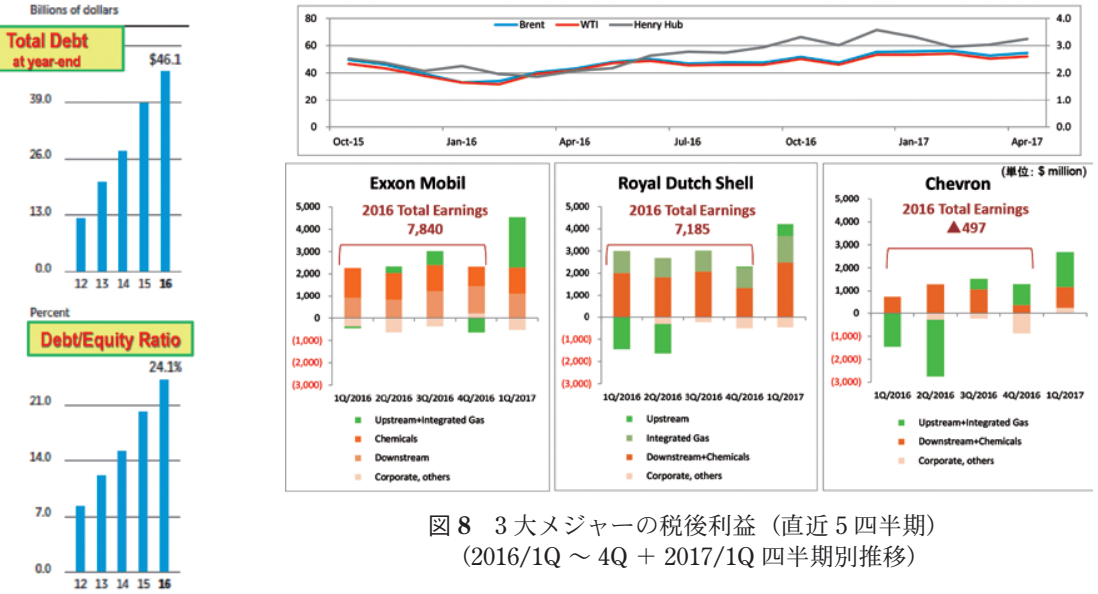

図 83 大メジャ一の税後利益（直近 5 四半期) (2016/1Q 4Q + 2017/1Q 四半期別推移)

図 4 主要財務指標 $\Leftrightarrow$ 健全性脆弱化の推移事例

【Chevron】（2012 年～2016 年）

\begin{tabular}{|c|c|c|c|c|c|c|c|c|c|c|c|c|c|c|c|c|c|c|}
\hline \multirow[b]{2}{*}{ (単位: \$ Million) } & \multicolumn{3}{|c|}{ 1Q/2016 } & \multicolumn{3}{|c|}{$2 Q / 2016$} & \multicolumn{3}{|c|}{$3 Q / 2016$} & \multicolumn{3}{|c|}{$4 Q / 2016$} & \multicolumn{3}{|c|}{$2016 \mathrm{CY}$} & \multicolumn{3}{|c|}{ 1Q/2017 } \\
\hline & XoM & RDS & $\mathrm{cVX}$ & XOM & RDS & $\mathrm{cvX}$ & XOM & RDS & $\mathrm{cVX}$ & XOM & RDS & CVX & XOM & RDS & $\mathrm{CVX}$ & XOM & RDS & CVX \\
\hline Reported Earings & 1,810 & 1,553 & (725) & 1,700 & 1,045 & $(1,470)$ & 2,650 & 2,792 & 1,283 & 1,680 & 1,795 & 415 & 7,840 & 7,185 & (497) & 4,010 & 3,754 & 2,682 \\
\hline $\begin{array}{l}\text { Upstream } \\
\text { Integrated Gas }\end{array}$ & (76) & $\left.\begin{array}{r}(1,437) \\
994\end{array}\right]$ & $(1,459)$ & 294 & $\begin{array}{r}(1,325) \\
868\end{array}$ & $(2,462)$ & 620 & $\begin{array}{r}4 \\
931\end{array}$ & 454 & (642) & $\begin{array}{r}54 \\
907\end{array}$ & 930 & 196 & $\begin{array}{r}(2,704) \\
3,700\end{array}$ & $(2,537)$ & 2,252 & $\begin{array}{r}540 \\
1,181\end{array}$ & 1,517 \\
\hline $\begin{array}{l}\text { Downstream } \\
\text { Chemicals }\end{array}$ & $\begin{array}{r}906 \\
1,355\end{array}$ & 2,010 & 735 & \begin{tabular}{r|}
825 \\
1,217
\end{tabular} & 1,816 & 1,278 & $\begin{array}{l}1,229 \\
1,171\end{array}$ & 2,078 & 1,065 & $\begin{array}{r}1,241 \\
872\end{array}$ & 1,339 & 357 & $\begin{array}{l}4,201 \\
4,615\end{array}$ & 7,243 & 3,435 & $\begin{array}{l}1,116 \\
1,171\end{array}$ & 2,489 & 926 \\
\hline Corporate, others & (375) & (14) & (1)] & (636) & (314) & (286) & (370) & (221) & (236) & 209 & (505) & (872) & $(1,172)$ & $(1,054)$ & $(1,395]$ & (529) & (456) & 239 \\
\hline Cash Flows & XOM & RDS & cVX & XOM & RDS & $\mathrm{cVX}$ & XOM & RDS & CVX & XOM & RDS & CVX & XOM & RDS & CVX & XOM & RDS & cVX \\
\hline 期首Cash 理高 & 3,705 & 31,752 & 11,022 & 4,846 & 11,019 & 8,562 & 4,358 & 15,222 & 8,764 & 5,093 & 19,984 & 7,351 & 3,705 & 31,752 & 11,022 & 4,225 & 19,130 & 6,988 \\
\hline CF from Operation & 4,812 & 661 & 1,141 & 4,519 & 2,292 & 2,531 & 5,355 & 8,492 & 5,311 & 7,396 & 9,170 & 3,863 & 22,082 & 20,615 & 12,846 & 8,173 & $\begin{array}{l}9,508 \\
\end{array}$ & 3,879 \\
\hline Asset Sales & 177 & 484 & 82 & 1,029 & 936 & 1,370 & 976 & 319 & 839 & 2,093 & 3,008 & 568 & 4,275 & 4,747 & 2,859 & 687 & 125 & 2,087 \\
\hline Net Debt lssuance & 11,935 & 264 & 3,788 & 1 & 9,472 & 2,703 & 0 & 8,219 & 476 & 102 & 189 & 489 & 12,038 & 18,144 & 7,456 & (875) & 364 & 900 \\
\hline Asset Acquisition & (234) & $(11,421)$ & 0 & (77) & 0 & 0 & $(1,087)$ & 0 & 0 & 549 & 0 & 0 & (849) & $(11,421)$ & 0 & $(1,738)$ & 0 & 0 \\
\hline Capital Expenditures & $(5,127)$ & $(5,324)$ & $(5,566)$ & $(5,158)$ & $(5,796)$ & $(4,357)$ & $(4,190)$ & $(5,282)$ & $(4,185)$ & $(4,829)$ & $(5,714)$ & $(3,889)$ & $(19,304)$ & $(22,116)$ & $(17,997)$ & $(4,169)$ & $(4,306)$ & $(3,315$ \\
\hline Cash Dividend Paid & $(3,054)$ & $(2,258)$ & $(2,000)$ & $(3,133)$ & $(2,436)$ & $(2,002)$ & $(3,133)$ & $(2,660)$ & $(2,005)$ & $(3,133)$ & $(2,323)$ & $(2,025)$ & $(12,453)$ & $(9,677)$ & $(8,032)$ & $(3,134)$ & $(2,654)$ & $(2,029$ \\
\hline Other Cash-In/Out & $(7,368)$ & $(3,139)$ & 95 & 2,331 & (265) & (43) & 2,814 & $(4,326)]$ & $(1,849)]$ & $(3,046)$ & $(5,184)$ & 631 & $(5,269)$ & $(12,914)$ & $(1,166)$ & 2,296 & $(2,572)$ & $(1,527$ \\
\hline 期中Cash增減 & 1,141 & $(20,733)$ & $(2,460)$ & (488) & 4,203 & 202 & 735 & 4,762 & $(1,413)$ & (868) & (854) & (363) & 520 & $(12,622)$ & $(4,034)$ & 1,240 & 465 & $(5$ \\
\hline 期末 Cash 残高 & 4,846 & 11,019 & 8,562 & 4,358 & 15,222 & 8,764 & 5,093 & 19,984 & 7,351 & 4,225 & 19,130 & 6,988 & 4,225 & 19,130 & 6,988 & 5,465 & 19,595 & 6,983 \\
\hline (単位: \$ Billion) & XOM & RDS & $\mathrm{cVX}$ & XOM & RDS & $\mathrm{cVX}$ & XOM & RDS & $\mathrm{cVX}$ & XOM & RDS & $\mathrm{cVX}$ & XOM: & ExxonMot & & XOM & RDS & $\mathrm{cVX}$ \\
\hline 末Total Debt & 43 & 80.9 & 42.3 & 44.5 & 90.3 & 45.1 & 46.2 & 97.8 & 45.6 & 42.8 & 92.5 & 46.1 & RDS: & Shell & & 43.6 & 91.6 & 45.3 \\
\hline DIE Ratio & $19.5 \%$ & $26.1 \%$ & $22.0 \%$ & $20.1 \%$ & $28.1 \%$ & $23.5 \%$ & $20.7 \%$ & $29.2 \%$ & $23.7 \%$ & $19.7 \%$ & $28.0 \%$ & 24.1\% & cvX: & Chevron & & $19.2 \%$ & $27.2 \%$ & $23.6 \%$ \\
\hline
\end{tabular}

図 73 大メジャーの業績・財務状況 2016 年 $(1 \mathrm{Q}-4 \mathrm{Q})+2017$ 年 $1 \mathrm{Q}$

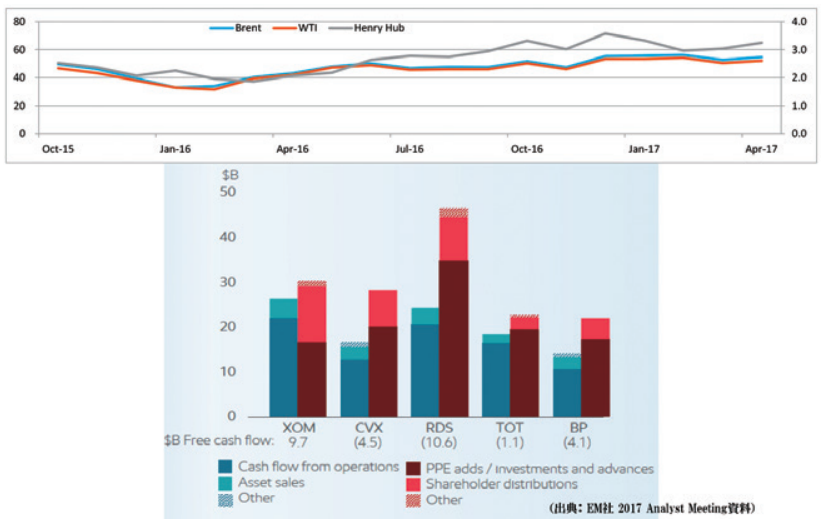

図 9 メジャー各社の Cash Flow 状況（2016 年）

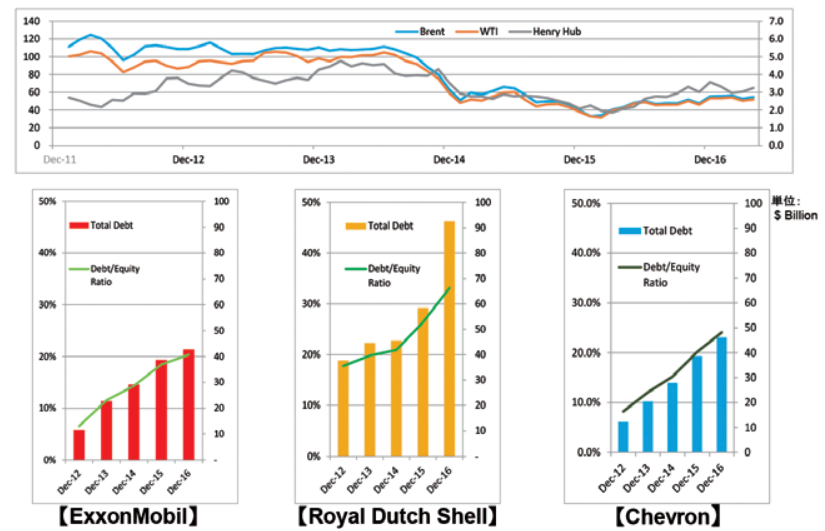

図 103 大メジャーの借入金 (Total Debt) および D/E Ratio 推移 (2012 年 2016 年) 


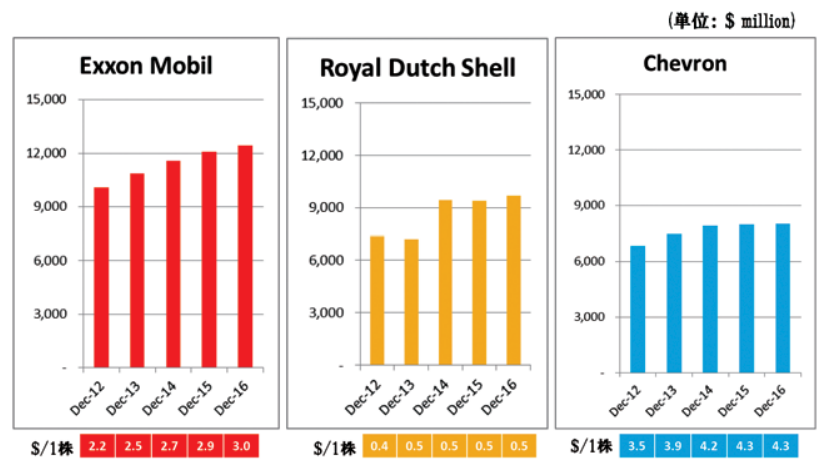

図 11 株主への現金配当の実績推移

一総支払額（棒グラフ）および配当単価（\$/1 株）-

Improving free cash flow

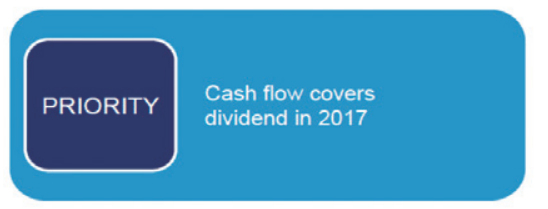

Maintain and grow dividend

Fund

capital program

for future earnings

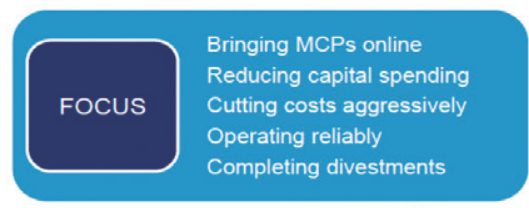

Maintain strong balance sheet

Return

surplus cash

to stockholders

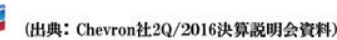

図 13 経営方針・優先課題の事例

【Chevron】（2016 年～ 2017 年）

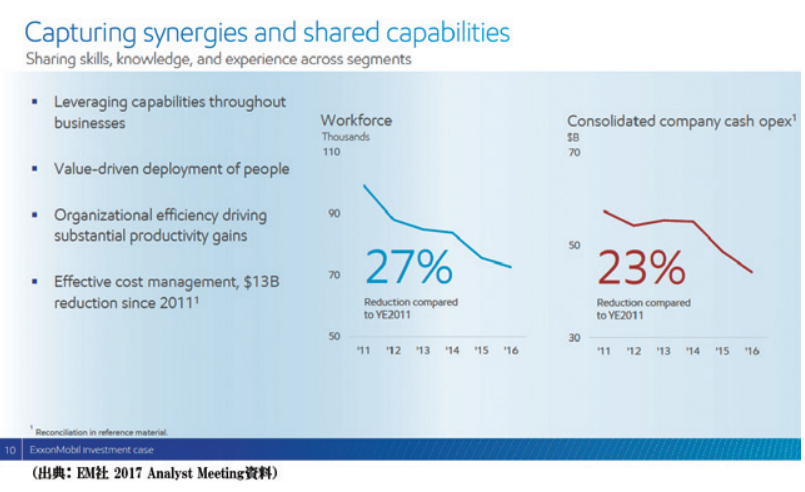

図 12 B/S リバランスに向けた取り組み事例 【ExxonMobil】 人員・コスト効率化

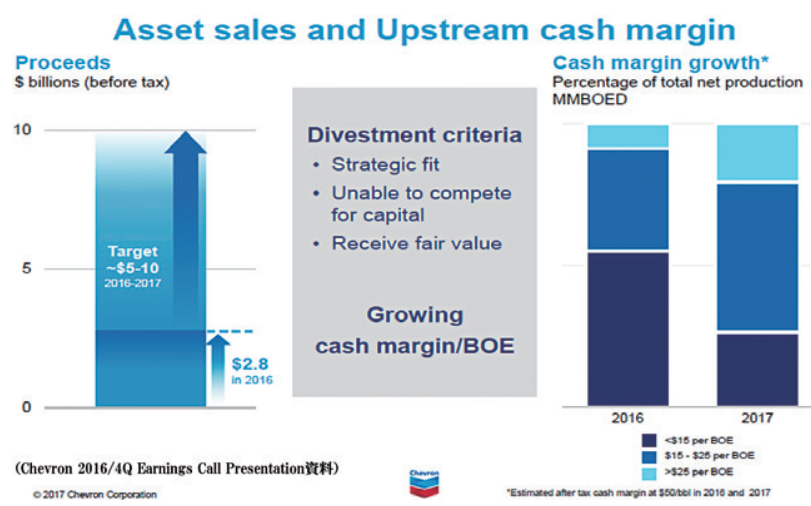

図 14 B/S リバランスに向けた取り組み状況

【Chevron】資産売却計画 + Cash Margin 改善の進捗状況
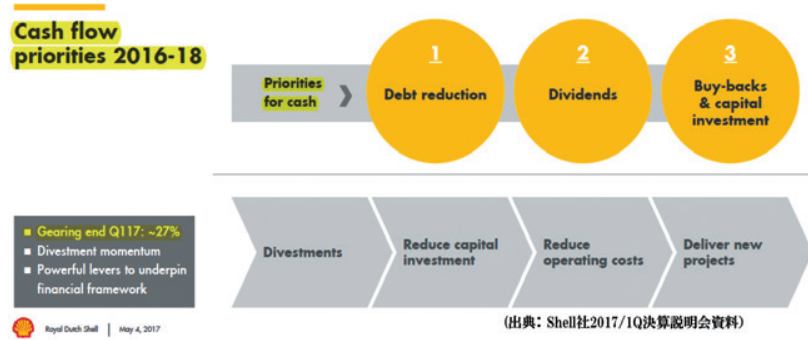

図 16 経営方針・優先課題の事例(2)

【Shell】（2016 年～ 2018 年）

図 15 経営方針・優先課題の事例(1)

【Shell】（2016 年 2018 年)
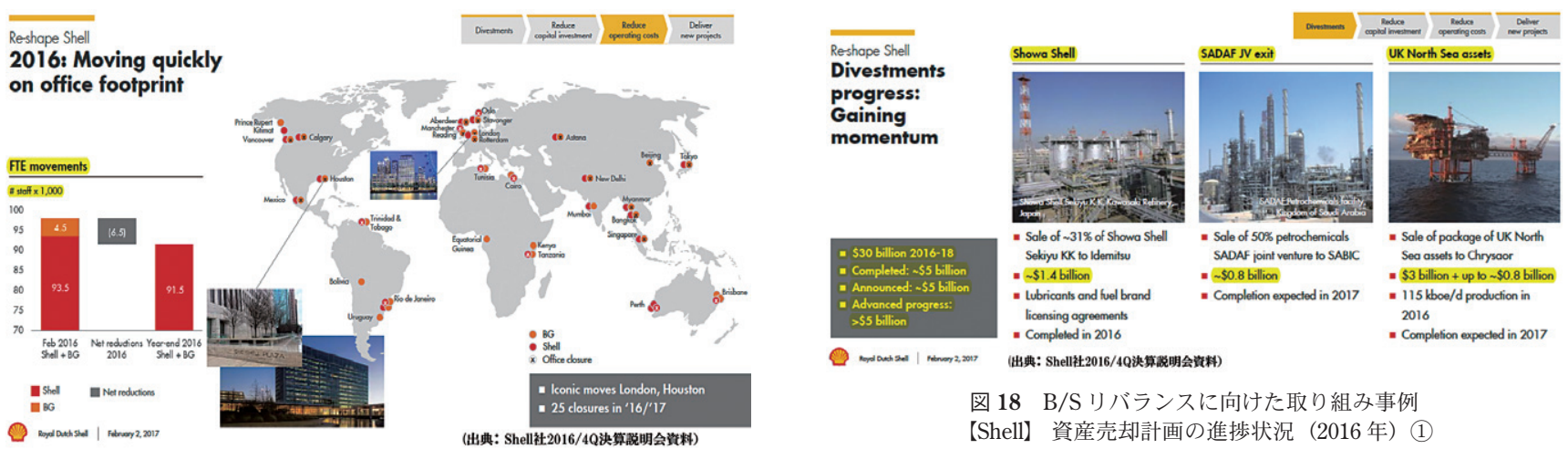

図 18 B/S リバランスに向けた取り組み事例 【Shell】資産売却計画の進渉状況（2016 年） (1)

図 17 B/S リバランスに向けた取り組み事例

【Shell】 BG 買収後の人員・事務所削減 


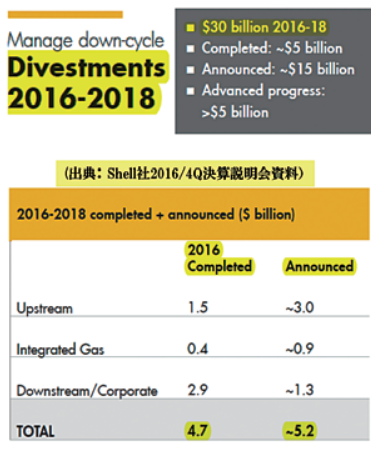

\begin{tabular}{|c|c|c|}
\hline 2016-2018 & 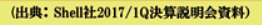 & S billion \\
\hline \multicolumn{2}{|c|}{ Total completed -2016} & -5.0 \\
\hline \multirow[t]{9}{*}{ Announced } & - AOSP \& other oil sonds assets in Canoda & -7.25 \\
\hline & - UKNorth Sea & -3.00 \\
\hline & - Motiva $N$ split & $-2.20 \mathrm{r}$ \\
\hline & - Thoilond - Bonglot & -0.90 \\
\hline & - Gobon onshore & -0.90 \\
\hline & -SADAF & -0.80 \\
\hline & - Australia criotion & -0.25 \\
\hline & - Vivo Energy - Africa & $-0.25 \mathrm{r}$ \\
\hline & - Hong Kong LPG & -0.15 \\
\hline \multicolumn{2}{|c|}{ Total announced } & -15.7 \\
\hline TOTAL & & -20.7 \\
\hline
\end{tabular}

図 19 B/S リバランスに向けた取り組み事例

【Shell】 資産売却計画の進渉状況（2016～2018 年）(2)

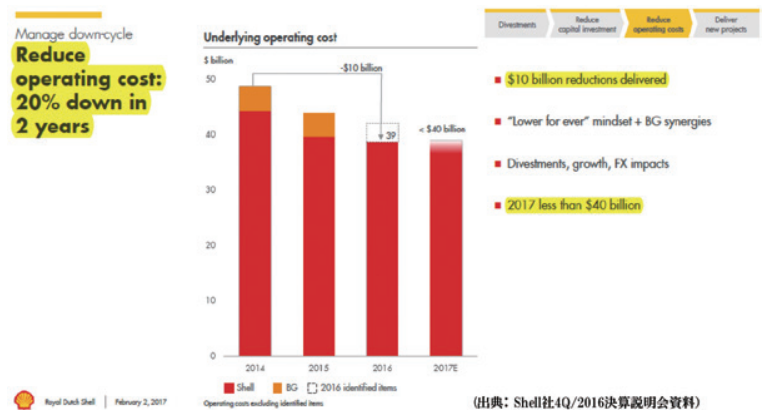

図 21 B/S リバランスに向けた取り組み事例 【Shell】 OPEX 削減状況

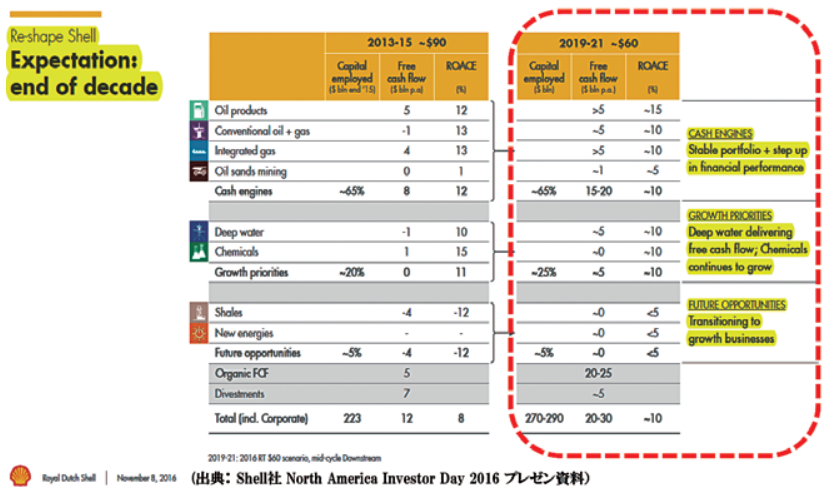

図 23 Mindset/Cultural Transformation 取り組み事例

【Shell】 2019-2021 年時点での Transformation 目標

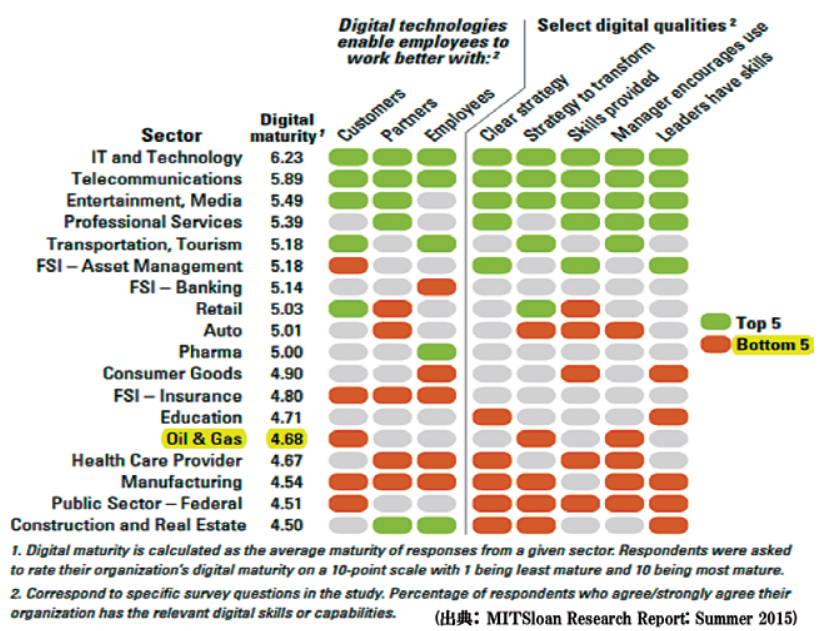

図 25 エネルギー業界は Digital Maturity 未成熟な業界!!

Standardization/Digitalization‥によるイノベーション余地は豊富

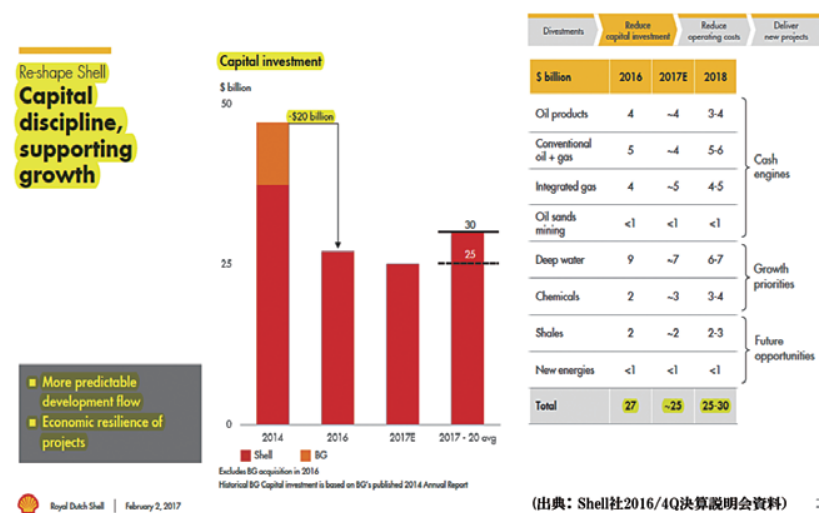

図 20 B/S リバランスに向けた取り組み事例

【Shell】投資予実状況と投資規律（2016～2018）

Spend reductions

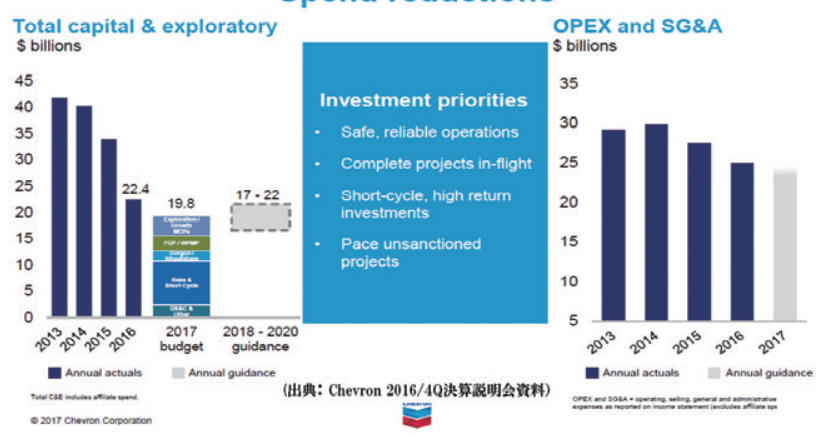

図 22 Mindset/Cultural Transformation 取り組み事例 【Chevron】投資規律

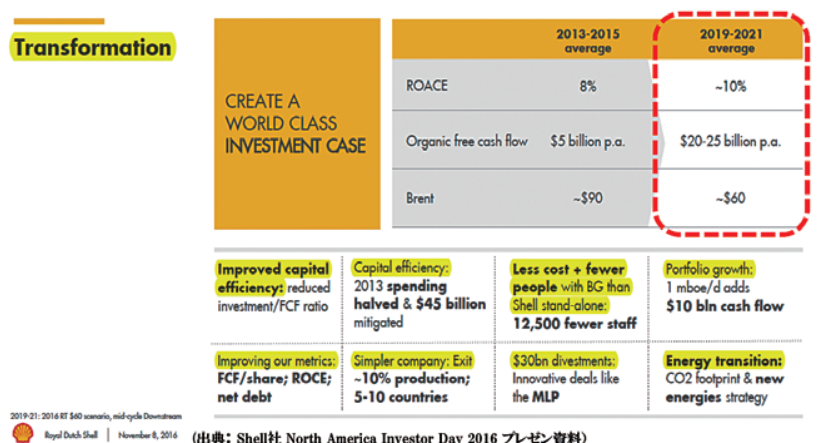

図 24 Mindset/Cultural Transformation 取り組み事例 【Shell】2019-2021 年時点での Transformation 目標

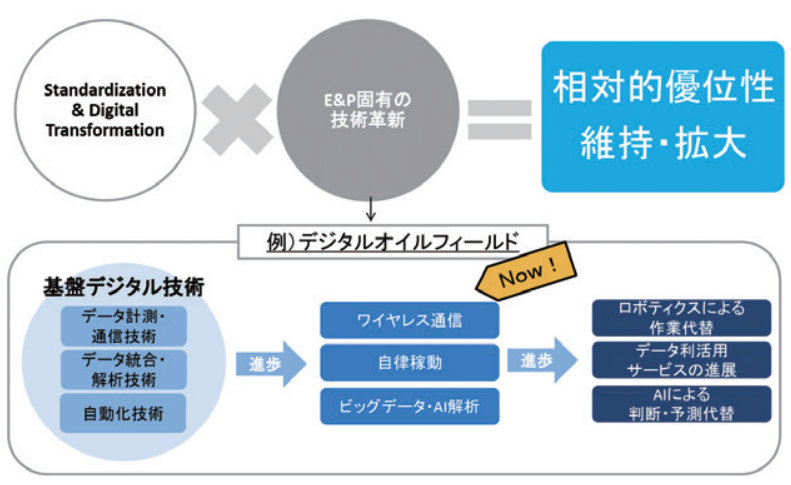

図 26 IT 技術による相対的優位性の維持・拡大

J. Japanese Assoc. Petrol. Technol. Vol. 82, No. 4 (2017) 


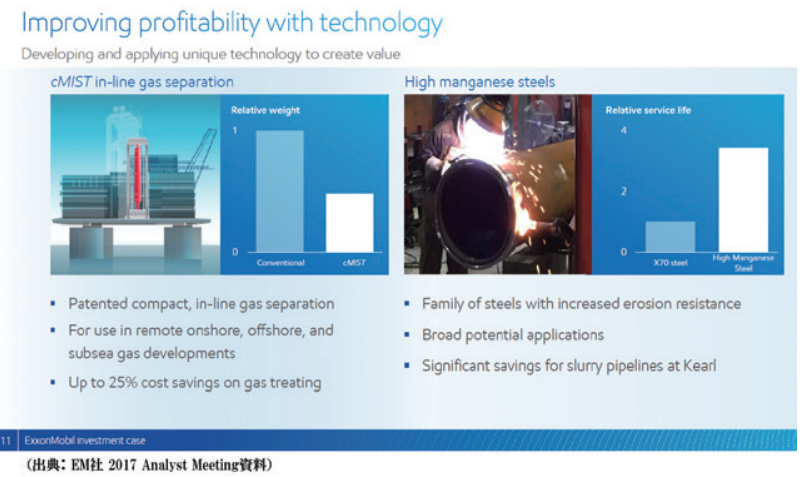

図 27 技術力進化への不断の取り組み事例 〔ExxonMobil】 技術革新
Addressing the risks of climate change

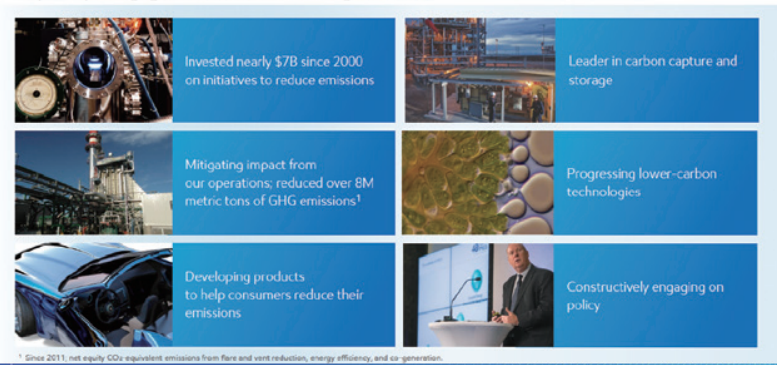

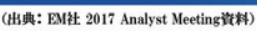

図 28 技術力進化への不断の取り組み事例 【ExxonMobil】低炭素社会・環境対応

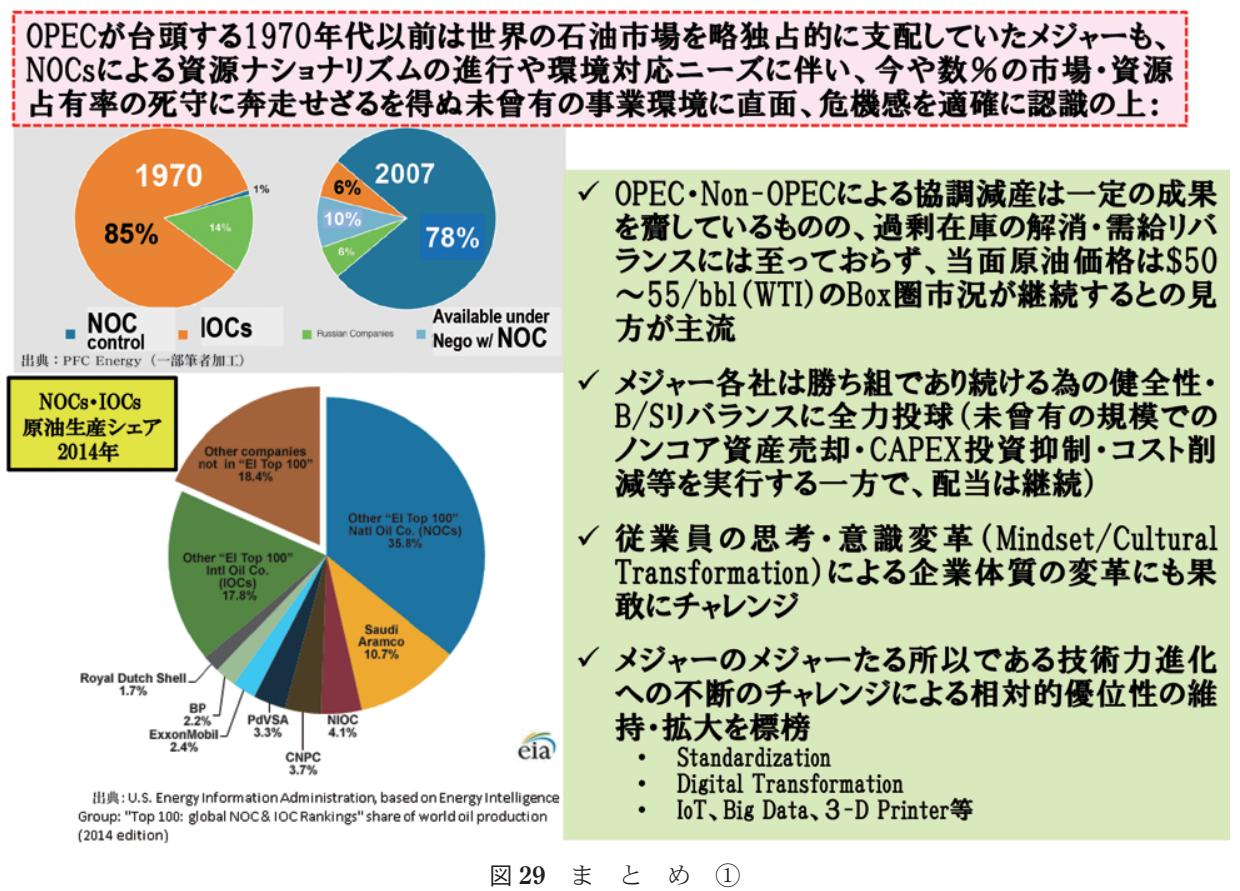

【地球温暖化や低炭素社会への長期予測】

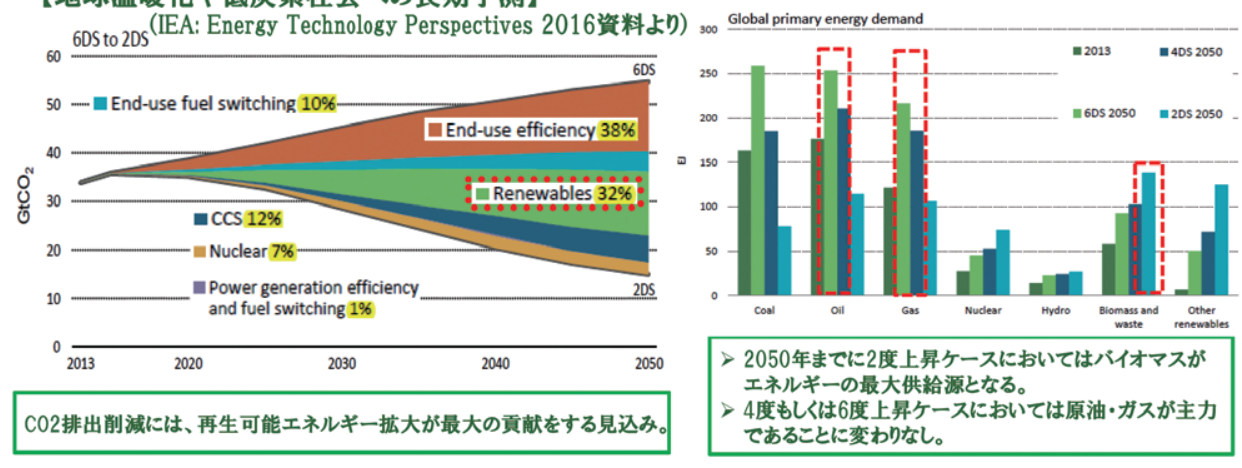

口 新興国の成長鈍化やCOP21等の影響を受け、引き続き低油価環境が継続することが予想される が、メジャー各社は「0il \& Gas First」の堅持をもって勝ち組てあり続ける為の自己変革の実現に よる持続的成長が経営の基軸。

口その一方て、技術力進化への不断のチャレンジを通して、地球温暖化や低炭素社会への耐性を 高める多様性の追求と、それによる社会貢献および企業価值向上にもより積極的に取組むものと 見込まれる。

口 日本企業も、こうしたメジャ一の動向を確り認識した上て、彼等メジャー企業とのパートナーシッフ 強化や、サービス提供企業を含めた上流事業ステークホールダーとのパートナー戦略、地域戦 略、NOC戦略等を既成概念に国わることなく検討·実行していくこど重要。 